\title{
ARTICULATE STUDIO FOR TEACHING AND LEARNING LANGUAGE
}

\author{
Asef Wildan Munfadlila, ${ }^{1}$ Deni Mustopa, ${ }^{2}$ Ismail Suardi Wekke ${ }^{3}$ \\ ${ }^{1}$ Stikes Bina Sehat PPNI Mojokerto, Jawa Timur, Indonesia \\ ${ }^{2}$ Universitas Islam Majapahit, Jawa Timur, Indonesia \\ ${ }^{3}$ STAIN Sorong, Papua Barat, Indonesia \\ Email: acheif90@gmail.com,
}

\begin{abstract}
The development of educational technology produces various educational concepts and practices that utilize media as a learning resource. Efforts to improve the quality of education have a variety of ways and in various components of education. To realize functions and achieve educational goals, improving the quality of learning in class is an important thing. The use of Articulate Studio in language teaching and learning is one of various ways as an alternative medium in the development of educational technology. Language classes only have activities once or twice a month that make students feel unable and the textbooks used there only provide limited practice for listening. To help teachers not only read listening scripts from books and use LCD, Audio, and Computer Laboratories available at school.
\end{abstract}

Key Words: Articulate Studio, Teaching Learning Language

\begin{abstract}
ABSTRAK
Perkembangan teknologi pendidikan menghasilkan berbagai konsep dan praktik pendidikan yang memanfaatkan media sebagai sumber belajar. Upaya peningkatan kualitas pendidikan memiliki berbagai cara dan pada berbagai komponen pendidikan. Untuk mewujudkan fungsi dan mencapai tujuan pendidikan, meningkatkan kualitas pembelajaran di kelas adalah satu hal yang penting. Penggunaan Articulate Studio dalam pengajaran dan pembelajaran bahasa adalah salah satu dari berbagai cara sebagai media alternatif dalam pengembangan teknologi pendidikan. Kelas bahasa hanya memiliki kegiatan sekali atau dua kali sebulan yang membuat siswa merasa tidak mampu dan buku teks yang digunakan di sana hanya
\end{abstract}


memberikan latihan terbatas untuk mendengarkan. Untuk membantu guru tidak hanya membaca skrip mendengarkan dari buku dan menggunakan LCD, Audio, dan Laboratorium Komputer yang tersedia di sekolah.

Key Words: Articulate Studio, Teaching Learning Language

\section{INTRODUCTION}

The government finally decided to try out the new designed curriculum, the 2013 curriculum. Thousands of schools, ranging from elementary (SD), junior high (SMP), and senior high (SMA) have participated in this try out. Despite the debate on the lack of preparation and infrastructure, the 2013 curriculum offers many new features in our education system. Unlike the previous one, the 2013 curriculum will be ITbased. Ministry of Education and Culture has set up a website to oversee the implementation of the 2013 curriculum.

The curriculum, however, scraps Computer or IT from the compulsory high school subjects. Students are not required to sit in the class for computer subject; rather, they can learn it outside classroom. For senior high school students, the 2013 curriculum gives them opportunity to learn other subjects from the other major. For example, a student from natural science major can take some subjects in social science or language/culture major, such as sociology or economy. Students can take whichever subject that they like. In fact, students are free to choose major and up to two crossmajor subjects as early as they enter senior high school. With this new feature, the Ministry hopes to abolish the paradigm that the students who get into natural science stream are smarter and better than the others.

The development of educational technology produces a variety of educational concept and practices that are making use of the media as learning resources. Improving the quality of education is absolutely necessary in order to improve the welfare of the nation. An effort to improve the quality of education is constantly being done in various ways and at various educational components. Training educators is continually held to provide insight and knowledge about the learning strategy deemed appropriate for each topic of learning and each level of education. To realize the functions and achieve educational goals, improving quality of learning in the classroom is one thing that is important. 
Nowadays English is the important subject in the world, this subject is used for the national exam in our country, and the English language is also used to communicate and to face the global era. Therefore, the learning of English should be applied and understood by students in daily live. To improve the quality of learning English so that the process of learning English in the classroom is successful, a model of learning English is an important issue. As noted by Arends (in Trianto), learning model can serve as an important mean of communication in the classroom learning process. ${ }^{1}$

Smith and Ragan suggest three indicators that can be used to determine the success of the learning process, which is effective, efficient, and attractive. ${ }^{2}$ Here in after mentioned, effective learning is learning that is able to bring students achieve learning objectives or competencies expected. While the significance of an efficient learning are an ongoing learning activities using time and resources which are relatively small. Lessons need to be created to be an interesting event to be able to increase the interest and motivation to study.

Students need media to improve their English skill. Articulate Studio gives the opportunity for student to increase their accessibility material and also for teacher exam in teaching learning process. Articulate Studio provides some facility for teacher to design the Listening Materials complete with quiz included, so the media will be a supplement for students to improve their ability and they will get the material and quiz.

With the development of technology, multimedia and e-learning teaching is increasingly accepted as a means of English language instruction. This model uses software called Articulate Studio which has appropriate feature to use Information Communication Technology in teaching learning process. The Software not only provided the text material, it also provided multimedia platform material like $\mathrm{mp}^{3}$, video, quiz, and assessment. It will be a good learning media to support teaching and learning process.

In addition, the software supports interactive material and assesment for education. So developing listening material using Articulate Studio for

\footnotetext{
${ }^{1}$ Trianto. Model Pembelajaran Terpadu dalam Teori dan Praktek, Jakarta: Prestasi Pustaka Publisher, 2007), h. 4.

${ }^{2}$ P. L. Smith, \& T. J. Ragan, Instructional Design (Third ed.). (Hoboken, NJ: John Wiley \& Sons, Inc., 2005), h. 10
} 
teaching and learning process necessary study, research and development of media.

\section{SOFTWARE PRESENTATION}

The design of media was conducted. Determining the themes, selecting the materials, and selecting the Software were required. Kinds of materials included are conversations, pictures, vocabulary, and quizzes. In listening activity provides fill the blank, matching words, multiple choices, in form of digital as interactive learning. There were two kinds of media for teacher and for students. For teacher were designed containing brainstorming, vocabulary, and examples of expression, and quizzes. For students were designed as quizzes for assessment in listening English skill activity.

In designing the concept of the material, software was considered. The software is Articulate Studio 13 decided to apply the listening material because it can display audio, video, picture, and also quizzes. The appearances are provided in the Articulate Studio 13 software.

The example of Articulate Studio appearances.

Figure 4.1.2.Quiz maker of Articulate Studio 13

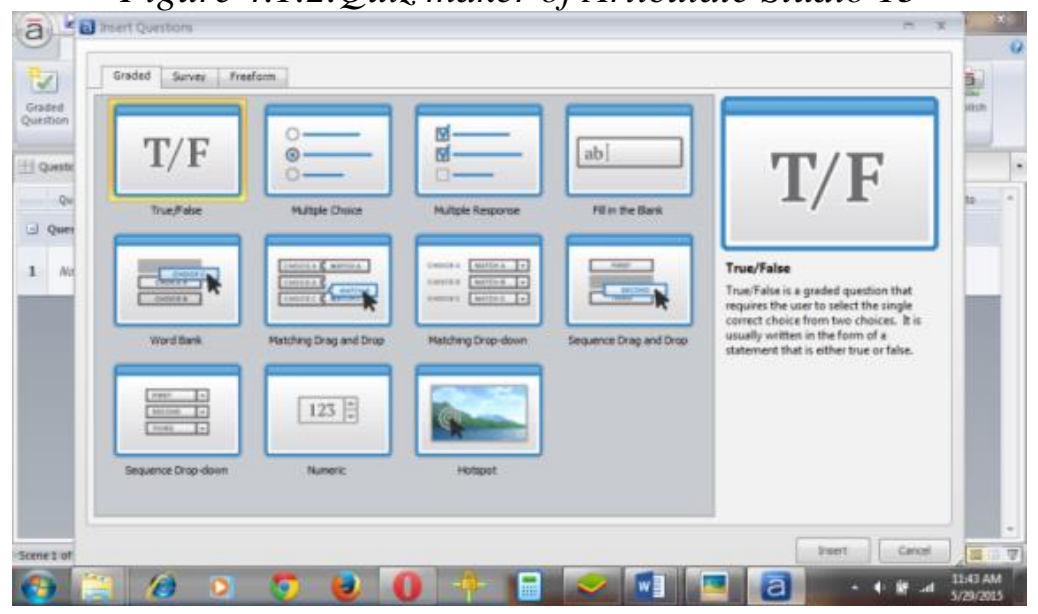


49 | Asef Wildan Munfadlila, Deni Mustopa, Ismail Suardi Wekke
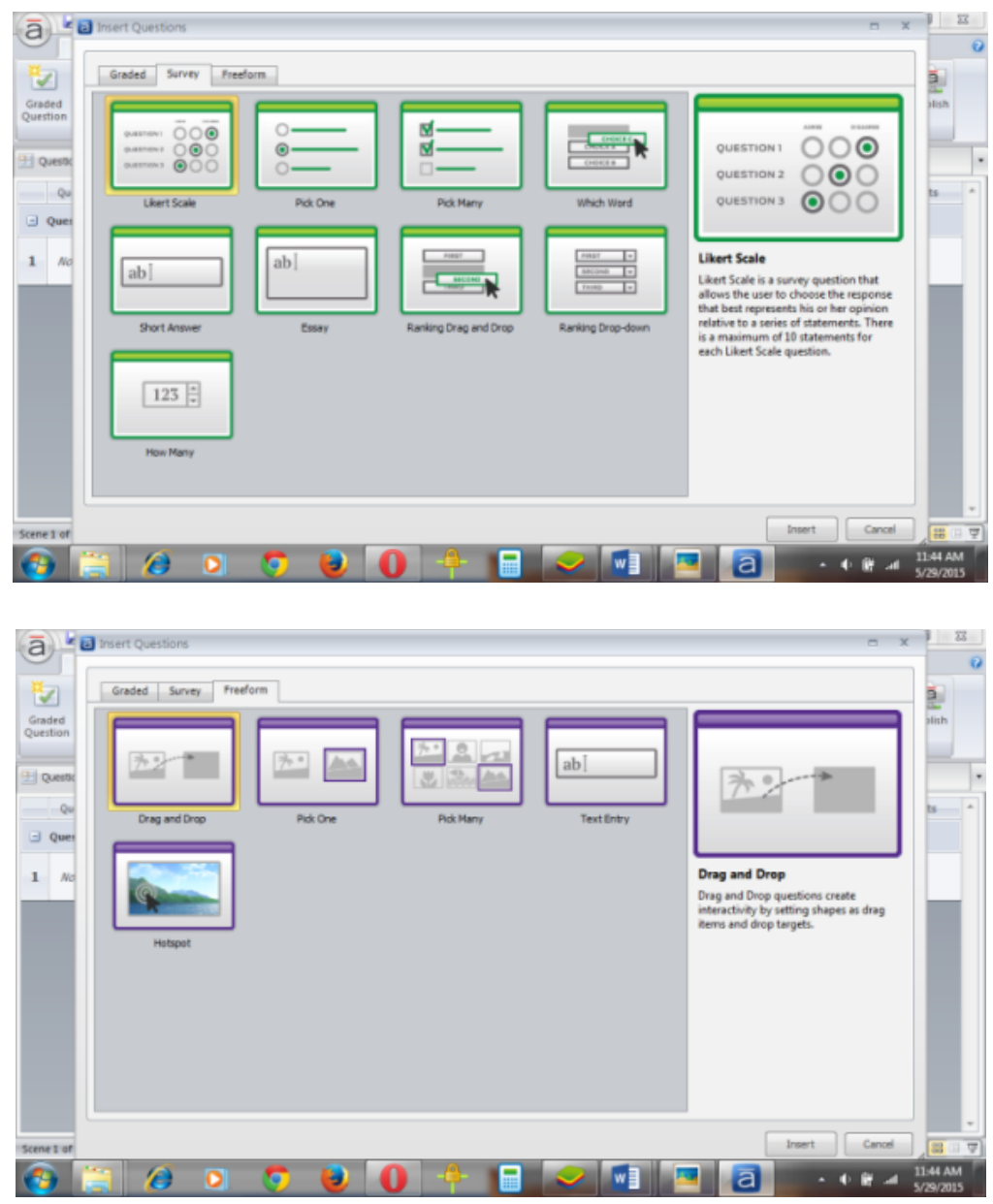

Figure 4.1.2.Engage maker of Articulate Studio 13 

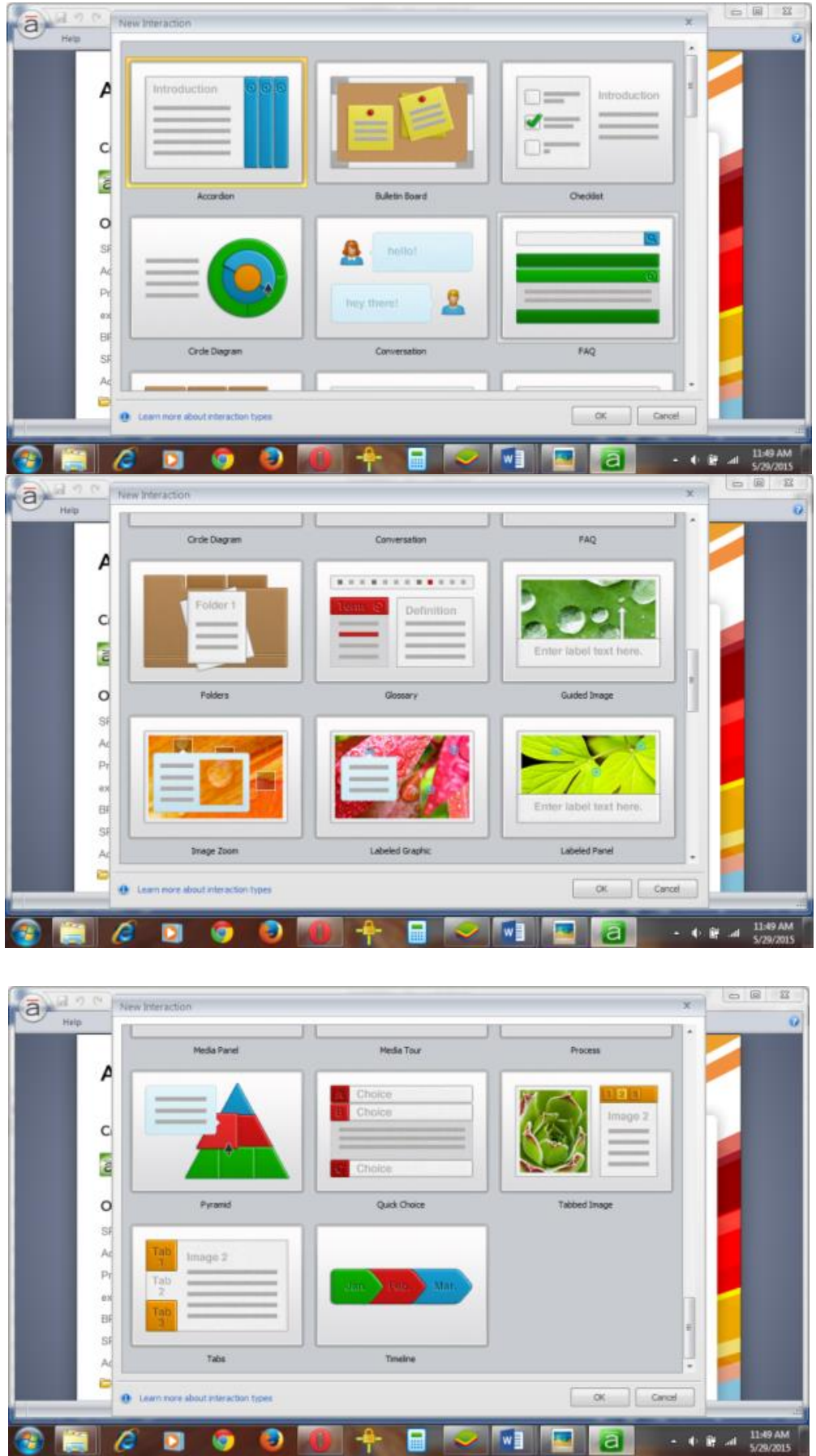


\section{APPLYING THE SOFTWARE FOR TEACHING ENGLISH}

Making quizzes for each unit are finished. So each unit in material has quiz to the student in developing listening material. Itcan also make teacher easy to assess the students in listening English skill. By giving vocabulary game each unit increase the student experience so that in media more interesting and help students to understand the difficult word and support their vocabulary. Here the revised product example

Figure 4.3 examples of media

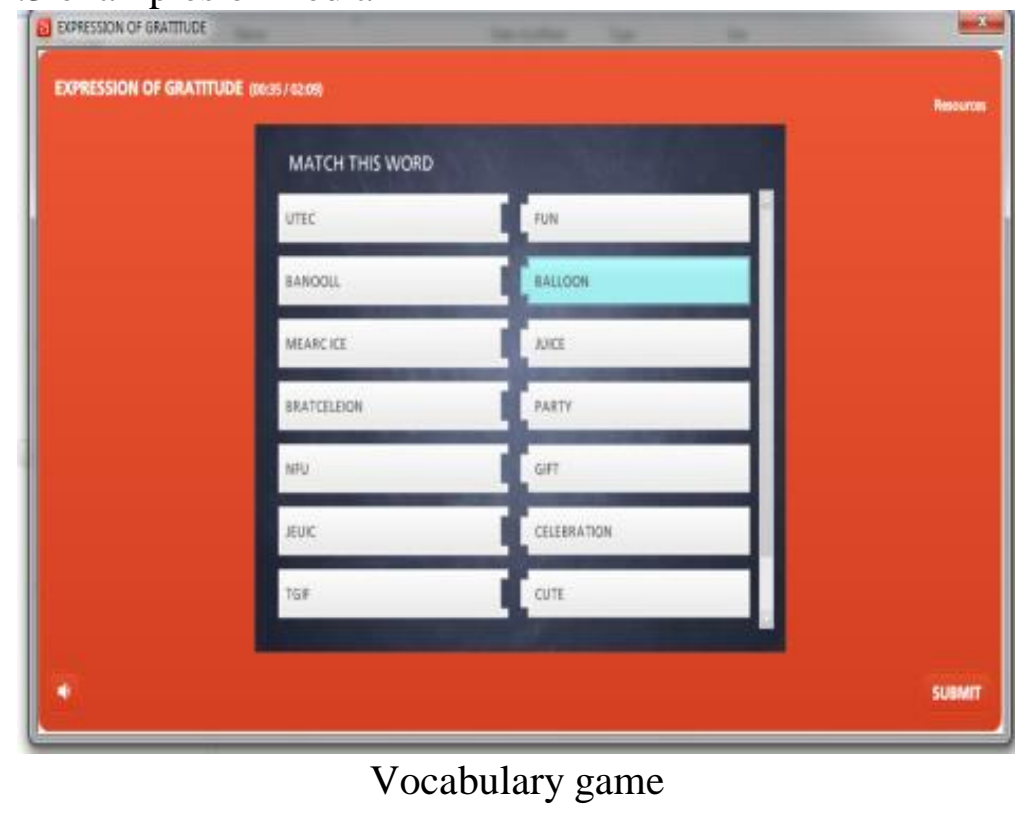




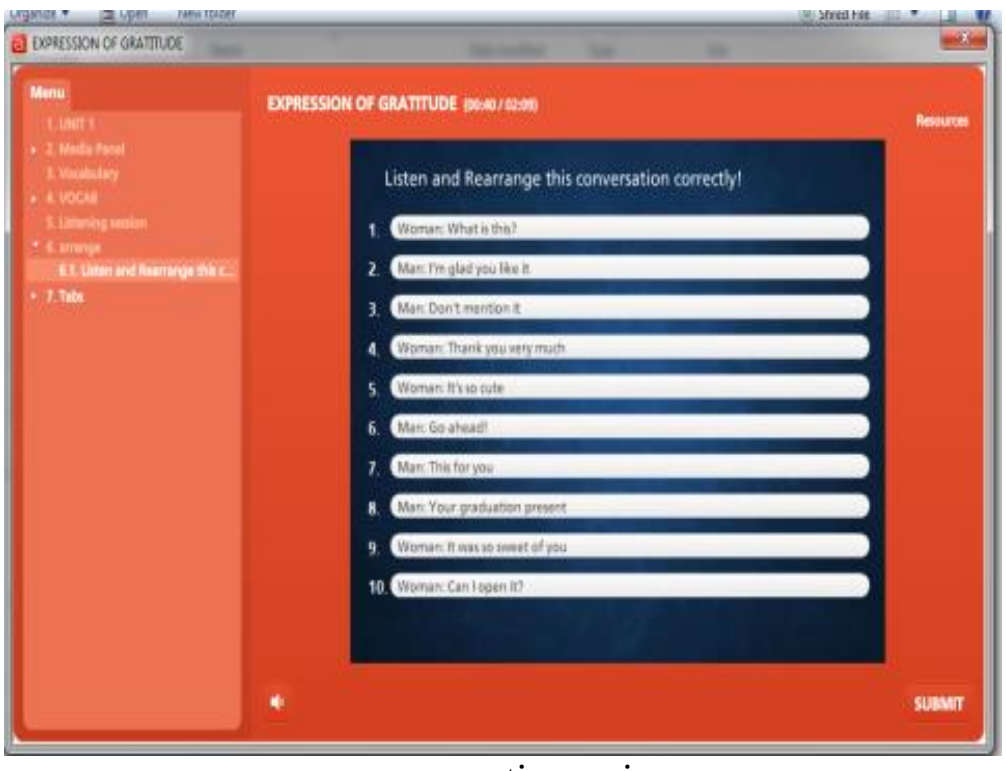

conversation quiz
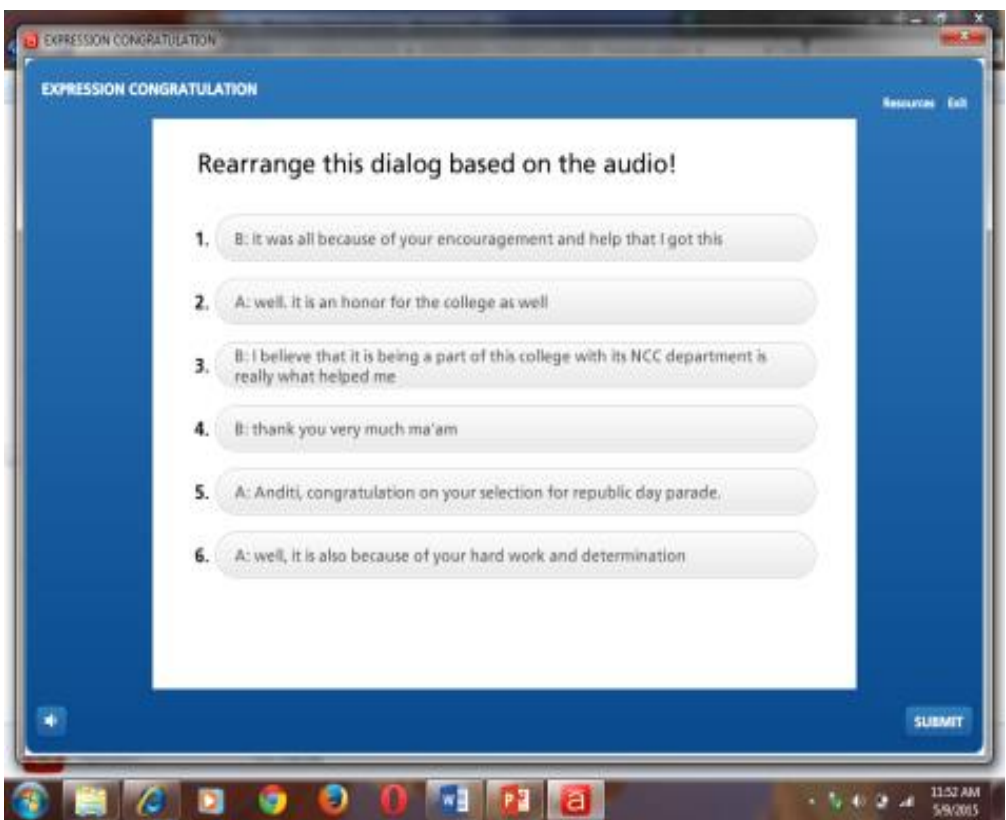

Another model of quiz 


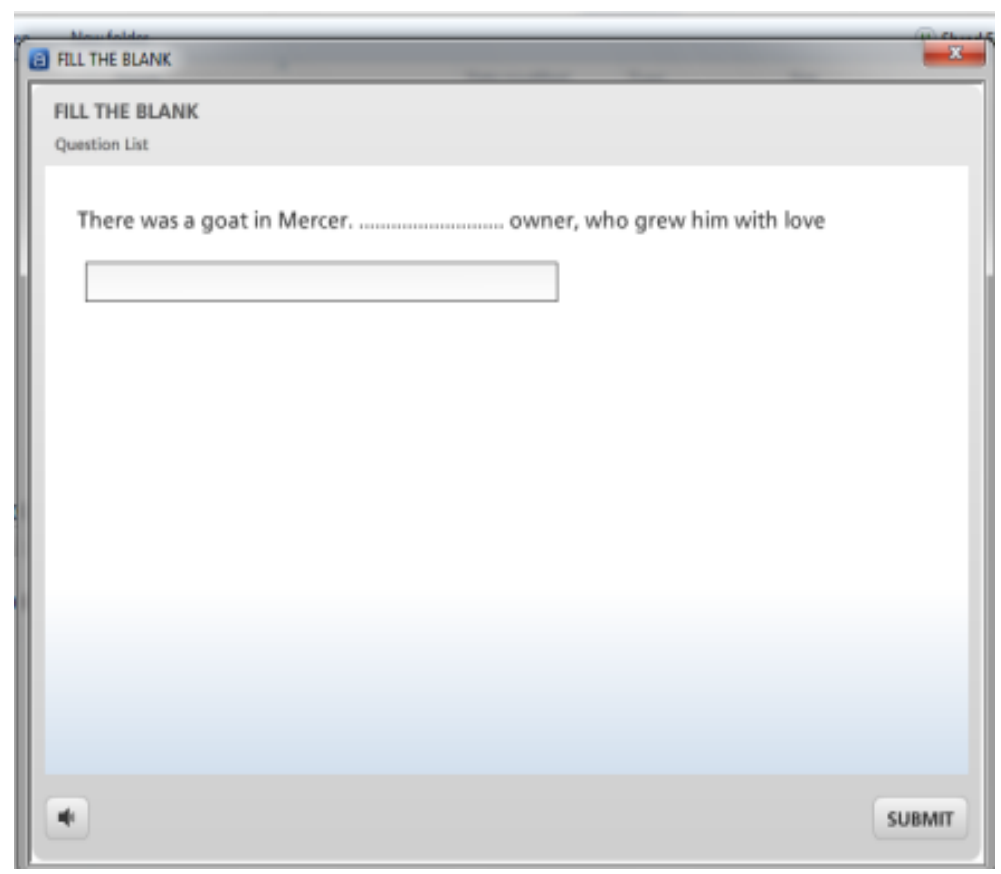

Blank sheet for monolog text quiz

Kinds of materials included are conversations, pictures, vocabulary, and quizzes. In listening activity provides fill the blank, matching words, multiple choices, in form of digital as interactive learning. There were two kinds of media for teacher and for students. For teacher are containing brainstorming, vocabulary, and examples of expression, and quizzes. For the students are as quizzes for assessment in listening English skill activity.

In designing the concept of the material, software was considered. The software is Articulate Studio 13 decided to apply the listening material because it can display audio, video, picture, and also quizzes. English listening media can cover in form of Compact Disk (CD), flashdisk, or online.

\section{CONCLUSION}

Articulate Studio 13 offers a lot of lot of features and contents and this LMS (Learning Management System) is the suitable web-based media for teaching and learning language. In short, Articulate Studio 13 provides some features such as; quiz, presenter, and engagement. The students can 
encourage more independent and active learning not only from the lecturer in the class. And also conversations, pictures, vocabulary, quizzes. In listening activity provides fill the blank, matching words, multiple choices, in form of digital as interactive learning.

This sub-chapter covers the conclusion and some recommendation which might be taken into consideration for English teachers and future researchers. The media is intended to be used by the students in self learning activitiesas well as teaching learning activities in the classroom. However, the teacher can also used theproduct as additional media in teaching listening in the class room. It is advisablethat the teacher develop the activities by adding more quizzes by digital or morefollow up activities.

\section{REFERENCE}

Borg, W.R \& Gall,M.D. 1983. EducationalResearch:An Introduction. (4thEd). White Plains: Longman, Inc.

Flowerdew and Miller, Linsey. 2005. Second language Listening: Theory and Practice. Newyork: Cambridge University Press.

Flowerdew, J. and Miller, L. (1996). "Student Perceptions, Problems and Strategies in Second Language Lecture Comprehension", RELC Journal 23 (2), 60-80.

Higgins, J.M.D. (1995). "Facilitating Listening in Second Language Classrooms Through the Manipulation of Temporal Variables". Unpublished Doctoral Thesis, University of Kent at Canterbury.

Meskill, C. 1996. "Listening Skills Development through Multimedia". Journal of Educational and Hypermedia, 5(2): 179-201.

Nunan, D. (1998). Second Language Teaching and Learning. Boston: Heinle\&Heinle.

Rost, M. (1994).Introducing listening. London: Penguin.

Rost, M. 2002. Teaching and Researching Listening. London:Longman.

Smith, P. L., \& Ragan, T. J. 2005. Instructional Design (Third ed.). Hoboken, NJ: John Wiley \& Sons, Inc. 
Trianto. 2007. Model Pembelajaran Terpadu dalam Teori dan Praktek. Jakarta: Prestasi Pustaka Publisher.

Wenden, A. (1986a). "Helping Language Learners Think About Learning”. English Language Teaching Journal, 40/1, 3-9.

Yagang, F. (1994). "Listening: Problems and Solutions". In T. Kral (ed.) Teacher Development: Making the Right Moves. Washington, DC: English Language Programs Divisions, USIA. 
Articulate Studio For Teaching And... | 56

\begin{tabular}{l|l} 
Jurnal Pendidikan Islam Vol. 17 No.1
\end{tabular} 